WSRC--RP--91-345

DE92. 018381

\title{
MODIFICATION OF K-14.1 SPARJET LOADING FOR LOSS OF TARGET ACCIDENT(U)
}

by

N. T. Hightower, III, and C. E. Morgan

Westinghouse Savannah River Company

Savannah River Site

Aiken, South Carolina 29808

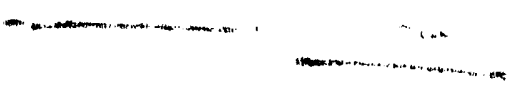

J3! 2 : 1992

The information contained in this document was prepared in connection with work done under Contract No. DE-AC09-89SR 18035 with the U.S. Department of Energy. By acceptance of this report, the publisher and/or recipient acknow'ledges the U.S. Government's right to retain a nonexclusive, royalty-free license in and to any copyright covering this report, along with the right to reproduce and to authorize others to reproduce all or part of the copyrighted report. 


\section{DISCLAIMER}

This report was prepared as an account of work sponsored by an agency of the United States Government. Neither the United States Government nor any agency thereof, nor any of their employees, makes any warranty, express or implied, or assumes any legal liability or responsibility for the accuracy, completeness, or usefulness of any information, apparatus, product, or process disclosed, or represents that its use would not infringe privately owned rights. Reference herein to any specific commercial product, process, or service by trade name, trademark, manufacturer, or otherwise does not necessarily constitute or imply its endorsement, recommendation, or favoring by the United States Government or any agency thereof. The views and opinions of authors expressed herein do not necessarily state or reflect those of the United States Government or any agency thereof.

This report has been reproduced directly from the best available copy.

Available to DOE and DOE contractors from the Office of Scientific and Technical Information, P.O. Box 62, Oak Ridge, TN 37831; prices available from (615) 576-8401, FTS 626-8401.

Available to the public from the National Techncial Information Service, U.S. Department of Commerce, 5285 Port Royal Rd., Springfield, VA 22161. 
WESTINGHOUSE SAVANNAH RIVER COMPANY SAVANNAH RIVER LABORATORY

KEY WORDS:

RETENTION TIME:
WSRC-RP-91-345

SRL-SAG-310128

K-14.1 RELOAD

LIFETIME

\section{DISTRIBUTION}

R. T. BEGLEY, 773-A

D. C. RICHARDSON, 773-A

J. D. SPENCER, 773-A

M. J. HITCHLER, 773-A

L. A. WOOTEN, $773.41 \mathrm{~A}$

N. T. HIGHTOWER, III, 773-69A

1. K. PAIK, 773-41A

J. R. CHANDLER, $773-41 A$

A. J. GARRETT, 773-A

T. W. BURNETT, 773-41A

D. A. SHARP, $773-41 \mathrm{~A}$

D. J. BAKER, 773-41A

T. E. BRITT, 676-14T

M. R. BUCKNER, 773-A

C. E. APPERSON, 773-42A

M. R. ROSSER, 707-C

C. G. NICKELL, 707-C

G. Z. MORGAN, 703-41A

B. STUBBS, 703-41A

T. HSIEH, 703-41A
P. D. RICE, 703-A
C. L. PECKINPAUG!: $70.4-C$
F. BERANEK, $70 \% \mathrm{C}$
H. F. ALIEN, $70 \%$ C
F. D. BENTON, 707-C
R.F. SWINGLE, 707.C
T. M. MONAHON, 707.C
A. M. VINCENT, III, 707-C
R. L. SALIZZONI, 707-C
C. M. SCHAUMAN, 707-C
S. D. CURRY, 707-C
D. W. CALL, 703-A
A. F. MCFARLANE, 703-A
G. H. CLARE, 703-31A
R. J. SKWAREK, 773-53A
V. S. O'BLOCK, 773-54A
D. S. LEACH, 773.53A
SRL RECORDS (4), 773-A
S. B. WHITFIELD (SAG FILE), 773-41A

P. D. RICE,

VICE PRESIDENT AND GENERAL MANAGER

REACTOR RESTART DIVISION

ATTENTION:

C. L. PECKINPAUGH,

DEPUTY GENERAL MANAGER

REACTOR OPERATIONS DEPARTMENT
F. BERANEK, MANAGER

REACTOR ENGINEERING DEPARTMENT

MODIFICATION OF K-14.1 SPARJET LOADING FOR LOSS OF TARGET ACCIDENT (U)

$\frac{1}{\text { SARM Derivative Classifier, Principal Engineer }}$ 


\section{INTRODUCTION AND SUMMARY}

Based on the current Loss Of Target Accident (LOTA) analysis, the Safety Anaivsis Group ( $S A G$ ) has found that the current practice concerning the loading of the sparjet shadow rods is to load 15 slugs and no spacer into the insert (also reterred to as the guide tube), such that the bottom of the bottom slug rests on tir: , wit botton end fitting. This places the bottom of the stack of lithium slugs about 10 inches below the lowest sparjet nozzles. There is no forced circulation in this region below the lowest sparjet nozzles, and all cooling must be by convection currents lifting warm water to mix with the forced convection through the lowest nozzles. While this heat removal mechanism appears to be adequate during normal operation, it does not provide a large margin for postulated flow reductions into the sparjet.

\section{RECOMMENDATIONS}

It is recommened that the "B" spacer be loaded as shown on drawings $\$ 5-1-1208$ and S3-1-219, such that the bottom of the stack of lithium slugs is at least 21 inches above the lowest sparjet nozzles. With this configuration, forced circulation through the lowest three levels of sparjet nozzles will remove the gamma and neutron moderation heating produced. This will provide the largest margin for postulated flow reductions into the sparjet. However, if the "B" spacer is not available, it is acceptable to load the "A" spacer as shown on drawings S5-1-1208 and S3-1-219.

This recommendation has been discussed with R.F. Swingle of RRD/ROD/RED and found to be acceptable.

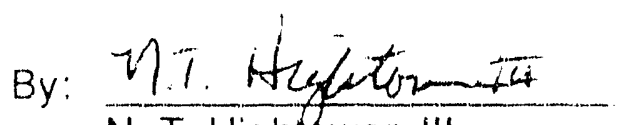

N. T. Hightower, III Lead Engineer, Non-LOCA Transient Analysis RSRS/Satety Analysis Group

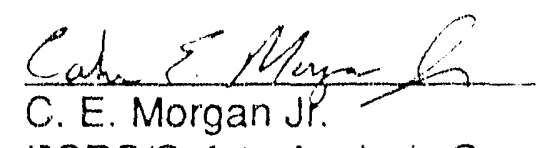

RSRS/Safety Analysis Group 
Technical

Review:

$\frac{1}{\text { K. Paik }}$

Principal Engineer,

RSRS/Safety Analysis Group

Approval:

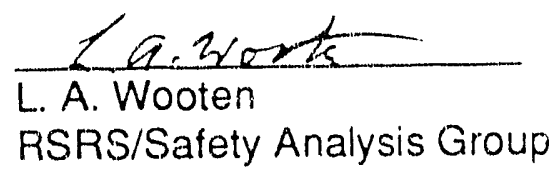




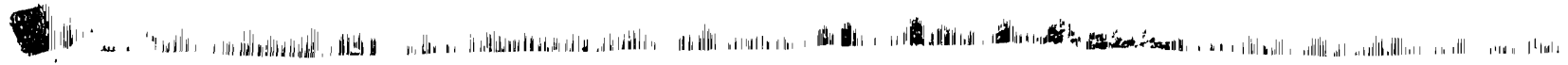
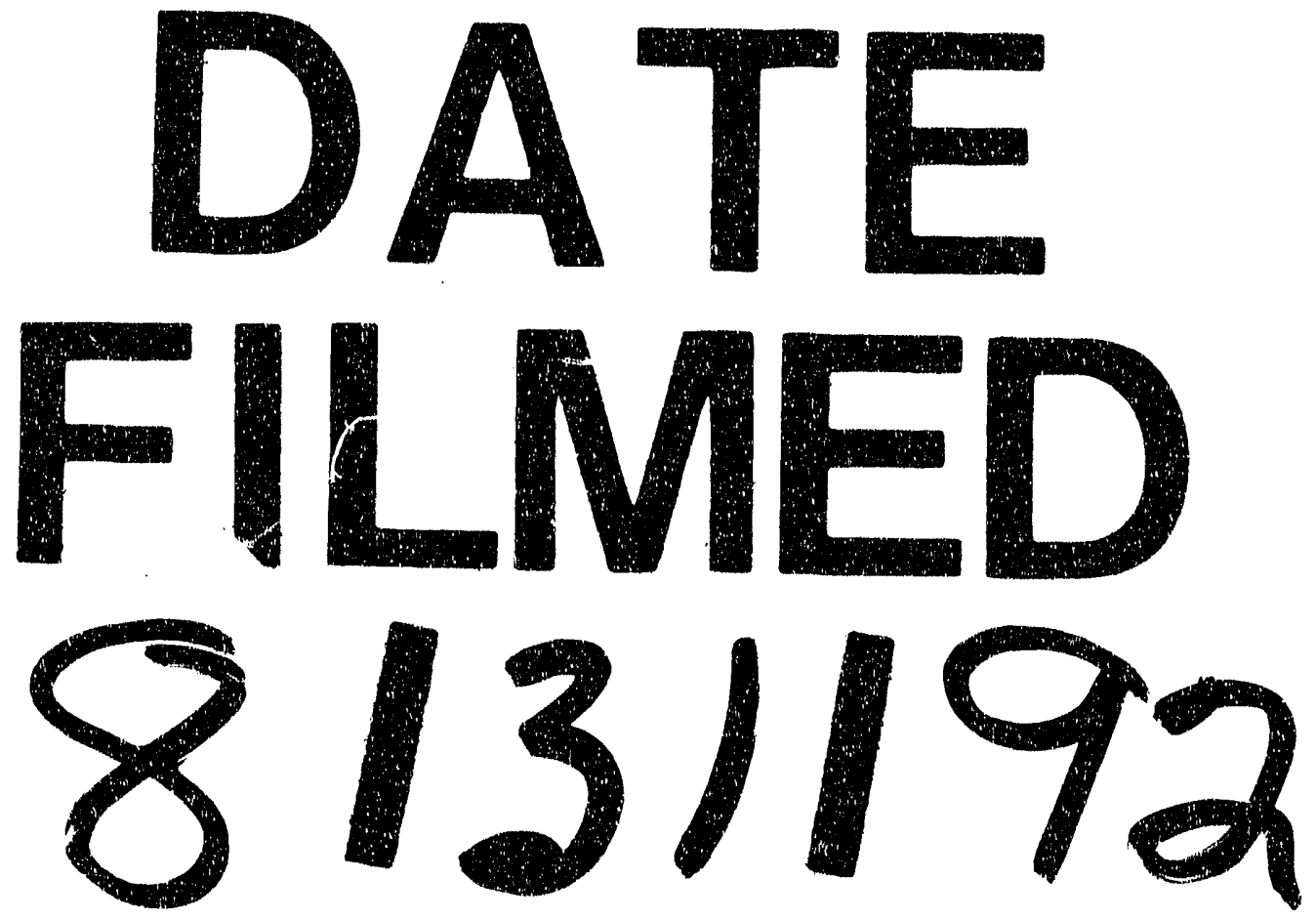
